\title{
Analisis Pengaruh Efektivitas Penerapan Sistem Manajemen Keselamatan dan Kesehatan Kerja (SMK3) Terhadap Produktivitas Kerja Karyawan (Studi Kasus Plant 11 PT Indocement Tunggal Prakarsa, Tbk Citeureup)
}

\author{
Rini Riestiany \\ Departemen Manajemen, Fakultas Ekonomi dan Manajemen, IPB \\ Ratih Maria Dhewi \\ Departemen Manajemen, Fakultas Ekonomi dan Manajemen, IPB \\ Sjafri Mangkuprawira \\ Departemen Manajemen, Fakultas Ekonomi dan Manajemen, IPB
}

\begin{abstract}
Employee is an important resource to have production process in a big factory. Factory couldn't operate without employee. To protect their employees, the leader makes a policy like occupational health and safety. This policy for protect their employee from risk of bad accident and illness that causes of work. Bad accident can strike employee anywhere and anytime so this cases must to have a special attention. So, the leader, government, and management must pay attention to this risk. Work accident leaning influence to manpower productivity because quality of work life and guarantee of occupational health and safety influence manpower productivity. PT Indocement Tunggal Prakarsa, Tbk is one of the biggest cement factories in Indonesia. This factory has applicated occupational health and safety assessment base on Permenaker No. 05/MEN/1996 and OHSAS 18001. Occupational health and safety effectiveness can describe by six aspect based on Miner Theory. That theory are safety training, safety publication, control to work environment, inspection and discipline, improvement awareness of occupational health and safety, report and statistic of occupational health and safety. Five aspect of Theory Miner, can describe by employee perspective, even report and statistic of occupational health and safety can describe by secondary data from Safety Department and Management Representative of PT ITP.
\end{abstract}

Keywords: Occupational Health and Safety, Manpower Productivity, Cement Factory.

\section{Pendahuluan}

Persaingan industri yang semakin kompetitif menuntut perusahaan lebih mengoptimalkan seluruh sumber daya yang dimilikinya. Oleh karenanya, tenaga kerja yang handal dan tangguh dibutuhkan dalam menunjang bisnis perusahaan agar dapat bersaing. Selain tenaga kerja (TK), perusahaan biasanya menggunakan mesin-mesin berteknologi tinggi dalam menunjang proses produksi, dengan tujuan meningkatkan produktivitas perusahaan, mencapai efektivitas, dan efisiensi. Penggunaan peralatan 
berteknologi tinggi menyebabkan timbulnya risiko keselamatan dan kesehatan bagi tenaga kerja. Risiko ini dapat menimpa tenaga kerja kapan dan di mana saja, sehingga membutuhkan perhatian khusus dari berbagai pihak yang terkait seperti tenaga kerja, pengusaha, pemerintah, dan manajemen. Risiko ini membuat tenaga kerja menyadari pentingnya lingkungan kerja yang sehat, aman, dan nyaman.

Berdasarkan data International Labor Organization (ILO), Indonesia menduduki peringkat ke-26 dari 27 negara yang diteliti pada tahun 2000-2003 untuk tingginya angka kecelakaan kerja yang terjadi (Mangkuprawira dan Vitayala 2007), yaitu 1.736 tenaga kerja meninggal dunia, namun bila dibandingkan sampai Januari 2004 yang mencapai 105.846 kasus, terdapat penurunan angka kecelakaan 9,9\% (www.gerbang.jabar.go.id), data tersebut menunjukkan kasus kecelakaan kerja di Indonesia masih relatif tinggi meskipun telah terjadi penurunan hingga Januari 2006.

UU No. 1 Tahun 1970 tentang Keselamatan dan Kesehatan Kerja (K3) dapat dijadikan acuan bagi perlindungan TK dari bahaya atau kecelakaan dan penyakit akibat kerja maupun akibat lingkungan kerja. Dengan diterapkannya program K3 diharapkan dapat membangun tenaga kerja produktif, sehat, dan bermutu. Penerapan K3 yang baik dan terarah dalam suatu wadah industri akan berdampak lain yaitu menghasilkan SDM bermutu, terampil, dan professional.

PT Indocement Tunggal Prakarsa, Tbk (PT ITP) merupakan perusahaan industri yang mengubah bahan mentah menjadi bahan setengah jadi dan atau bahan jadi. PT ITP adalah salah satu produsen semen terbesar di Indonesia. Proses produksi semen melibatkan kontak langsung antara karyawan dengan mesin-mesin dan alat-alat teknologi tinggi, serta bahan-bahan kimia, sehingga cenderung memiliki risiko kecelakaan tinggi.

Untuk menurunkan tingkat kecelakaan kerja dan untuk meningkatkan produktivitas kerja karyawan, PT ITP membuat program K3 sejak tahun 1999 yang mengacu pada Permenaker No. 05/MEN/1996. Dengan diterapkannya K3 ini, PT ITP berusaha untuk terus meningkatkan program K3 yang telah diintegrasikan menjadi Sistem Manajemen K3 (SMK3) yang bertujuan agar pengelolaan K3 dapat lebih menyeluruh dengan penerapannya yang diperuntukkan bagi seluruh karyawan yang bekerja baik di dalam kantor maupun di lapangan. SMK3 merupakan bagian dari manajemen secara keseluruhan yang meliputi struktur organisasi, kegiatan perencanaan, tanggungjawab, pelaksanaan, prosedur, proses dan sumber daya yang dibutuhkan untuk pengembangan, pengkajian, dan pemeliharaan kebijakan $\mathrm{K} 3$.

Salah satu jenis unit produksi di PT ITP yaitu plant. Plant mempunyai risiko kecelakaan kerja yang tinggi, karena menggunakan peralatan canggih dan berteknologi tinggi. Plant 11 (P-11) merupakan salah satu plant terbesar yang dimiliki PT ITP. P-11 mulai beroperasi pada Maret 1999 dan menerapkan program K3 serta tahun 2000 diintegrasikan menjadi SMK3. Semenjak diterapkannya SMK3 ini, pelaksanaannya ditunjang oleh SubP2K3, dengan tujuan memantau segala perkembangan dan kegiatan yang dilakukan perusahaan.

PT ITP telah berusaha agar penerapan SMK3 dapat dilaksanakan dengan baik, namun kecelakaan masih sering terjadi. Hal ini ditunjukkan dari jumlah kecelakaan yang mencapai 47 kejadian dari bulan Januari hingga Juni 2007. Sebanyak 39 kejadian 
kecelakaan terjadi di plant dan $82,98 \%$ terjadi karena tindakan-tindakan karyawan yang berbahaya (Unsafe Action).

Kecelakaan kerja dikhawatirkan mempengaruhi produktivitas kerja karyawan. Salah satu hal yang mempengaruhi produktivitas kerja karyawan adalah lingkungan tempat karyawan bekerja dan jaminan terhadap risiko keselamatan dan kesehatan kerja. Oleh karena itu, PT ITP perlu melakukan peninjauan ulang kembali pelaksanaan SMK3 dengan berbagai cara, antara lain menggunakan data sekunder P-11 saat mulai beroperasi dan diterapkan SMK3 hingga saat ini lalu membandingkan data kecelakaan yang terjadi selama itu. Penelitian ini bertujuan mengkaji pelaksanaan SMK3 dan menganalisis efektivitasnya dalam mengurangi angka kecelakaan kerja, menganalisis tingkat produktivitas kerja karyawan, menganalisis pengaruh penerapan SMK3 terhadap produktivitas kerja karyawan, serta memberikan solusi alternatif agar pelaksanaan SMK3 dapat berjalan lebih baik lagi di P-11 PT ITP.

\section{Metode Penelitian}

Penelitian ini dilaksanakan di PT Indocement Tunggal Prakarsa, Tbk khususnya di P11 yang berada di Jalan Mayor Oking Jaya Atmaja Citeureup Bogor pada bulan Desember 2007 sampai dengan bulan Februari 2008.

Data yang digunakan dalam penelitian ini berupa data primer dan data sekunder. Data primer diperoleh melalui wawancara kepada karyawan dan beberapa unit departemen yang terkait dalam penelitian ini dan pengisian kuesioner oleh karyawan P-11 PT ITP yang dipilih secara proporsional random sampling sebanyak 134 orang dari tiga departemen unit kerja yaitu Production Departement, Mechanic Departemen, dan Electrical Department. Pengumpulan data sekunder dilakukan untuk data terkait dengan SMK3, statistika kecelakaan kerja berupa Injured Frequency Rate (IFR) dan Injured Severity Rate (ISR), produktivitas kerja karyawan, serta data-data lain yang diperoleh dari Safety Dept, Quality Save Measurement Ratio (QSMR), arsip P-11 dan berbagai literatur, baik berupa buku yang memuat teori-teori, hasil penelitian terdahulu, serta pencatatan data yang sudah ada di perusahaan.

Pengembangan SDM yang dilakukan oleh setiap perusahaan berbeda-beda tergantung pada kebutuhan SDM yang dimiliki. Untuk menghasilkan SDM kompeten, banyak faktor yang harus diperhatikan, salah satunya kenyamanan dan keamanan tempat kerja. Agar keamanan dan kenyamanan dirasakan oleh semua pihak yang bekerja, baik yang bekerja di dalam maupun di luar ruangan, konsep K3 ini diintegrasikan menjadi SMK3.

Penelitian ini dilaksanakan di P-11 PT ITP karena plant tersebut merupakan plant terbesar yang memiliki kecenderungan untuk terjadinya kecelakaan masih tinggi. Gambar 1 menunjukkan alur kerangka pemikiran dari penelitian ini. 


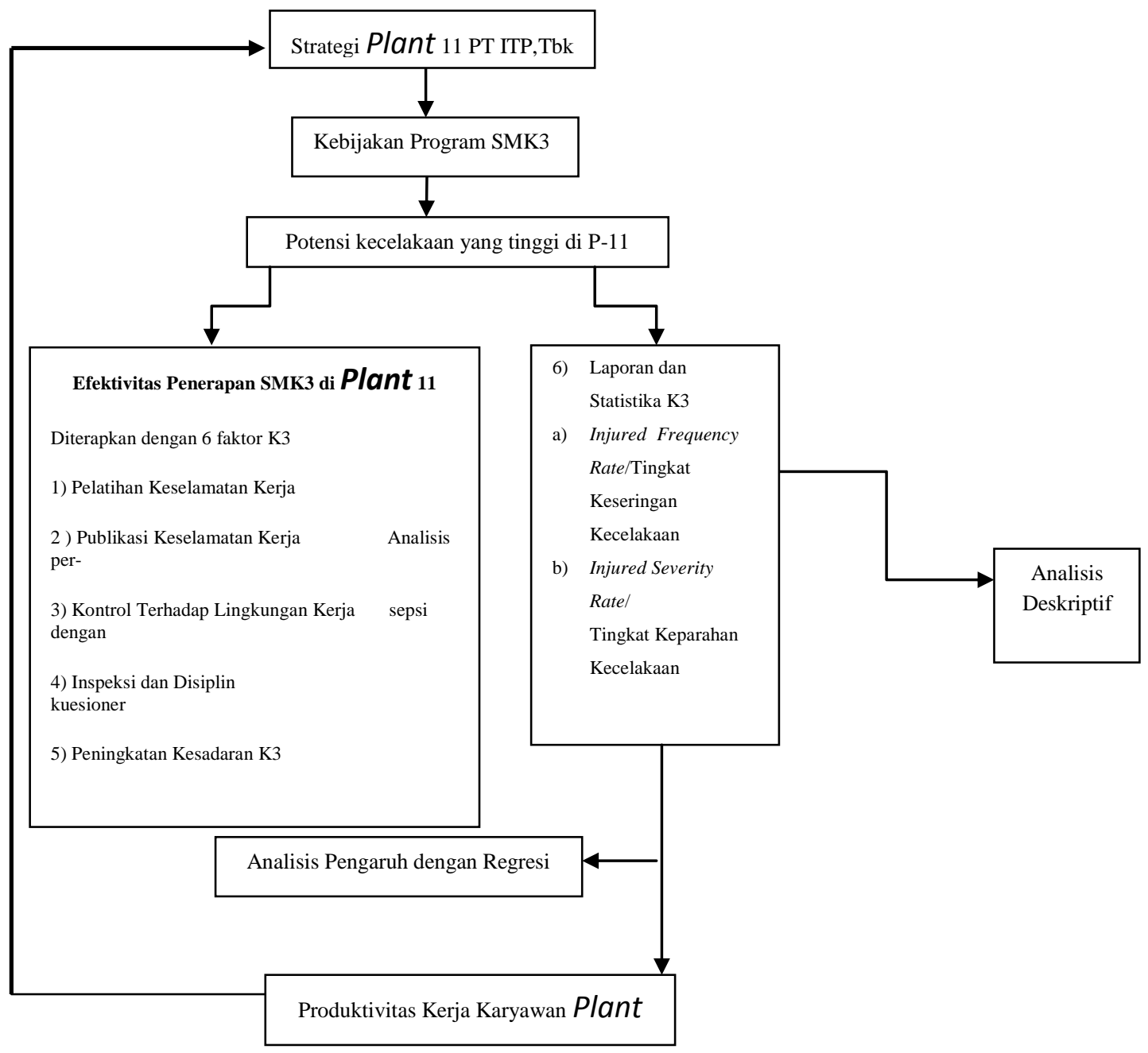

Gambar 1. Kerangka Pemikiran Penelitian

Kuesioner pada penelitian ini menggunakan empat pilihan jawaban dengan skala Ordinal yang digunakan untuk mengetahui penilaian seseorang terhadap sesuatu. Empat pilihan jawaban tersebut adalah sangat tidak setuju, tidak setuju, setuju, dan sangat setuju. Setiap jawaban dalam kuesioner diberikan skor, pada persamaan 1 diberikan cara menghitung skor rataan.

$$
\underline{\underline{\Sigma}}\left(\mathrm{X}_{\mathrm{i}} \cdot \mathrm{n}_{\mathrm{i}}\right)
$$

$\mathrm{n}$

Keterangan:

$\overline{\mathrm{X}}$ : skor rataan

$n_{i}$ : jumlah jawaban responden untuk skor $\mathrm{i}$

$\mathrm{x}_{\mathrm{i}}$ : skor nilai jawaban reponden $\mathrm{i}$

$\mathrm{n}$ : jumlah responden

Selanjutnya menggunakan rentang skala penilaian untuk menentukan posisi tanggapan responden dengan menggunakan nilai skor. Setiap skor alternatif yang terbentuk dari teknik skala peringkatan terdiri dari kisaran 1-4 yang menggambarkan posisi sangat negatif ke posisi positif, kemudian dihitung rentang skala dengan rumus berikut: 


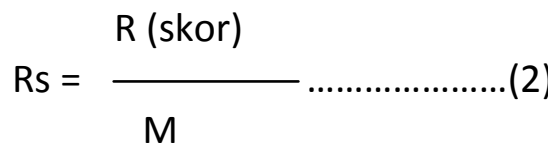

Keterangan:

Rs : skor terbesar - skor terkecil

$M$ : banyaknya kategori skor

Nilai skor rata-rata (Rs) yang didapatkan adalah 0,75.

Tabel 1. Posisi Keputusan Penilaian

\begin{tabular}{cc}
\hline Skor Rataan & Keterangan \\
\hline $1,00-1,75$ & Sangat tidak setuju \\
$1,75-2,5$ & Tidak setuju \\
$2,5-3,25$ & Setuju \\
$3,25-4,00$ & Sangat Setuju \\
\hline
\end{tabular}

Interpretasi untuk tiap posisi tersebut adalah:

1. Jika nilai skor rataan yang dihasilkan berada pada rentang $1,00-1,75$, pelaksanaan SMK3 dinyatakan sangat tidak baik

2. Jika nilai skor rataan yang dihasilkan berada pada rentang $1,75-2,5$, pelaksanaan SMK3 dinyatakan tidak baik

3. Jika nilai skor rataan yang dihasilkan berada pada rentang 2,5-3,25, pelaksanaan SMK3 dinyatakan baik

4. Jika nilai skor rataan yang dihasilkan berada pada rentang 3,25-4,00, pelaksanaan SMK3 dinyatakan sangat baik

1. Uji Validitas

Uji ini dilakukan untuk mengetahui sampai sejauhmana penyataan pada kuesioner dapat mengukur apa yang ingin diukur. Peubah-peubah dalam penelitian ini adalah produktivitas kerja karyawan sebagai peubah tidak bebas $(\mathrm{Y})$ dan penerapan SMK3 sebagai peubah bebas (X). Menurut Umar (2003), untuk menghitung analisa korelasi digunakan rumus:

$$
\mathrm{r}=\frac{\mathrm{n} \sum \mathrm{xy}-\left(\sum \mathrm{x}\right)\left(\sum \mathrm{y}\right)}{\sqrt{\left(\mathrm{n} \sum \mathrm{x}^{2}-\left(\sum \mathrm{x}\right)^{2}\right)\left(\mathrm{n} \sum \mathrm{y}^{2}-\left(\sum \mathrm{y}\right)^{2}\right)}}
$$

Keterangan:

$r \quad$ : koefisien korelasi

$\mathrm{n}$ : ukuran contoh

$\mathrm{Y}$ : peubah tidak bebas (produktivitas kerja karyawan)

$X$ : peubah bebas (penerapan SMK3)

Uji reliabilitas dilakukan setelah uji validitas. Uji reliabilitas menunjukkan konsistensi suatu alat pengukur di dalam gejala yang sama, sehingga diketahui sejauhmana alat ukur dapat diandalkan. Pengujian ini dilakukan dengan menggunakan rumus Alpha Cronbach's lalu membandingkannya dengan nilai $r$ tabel.

$$
\left[\frac{k}{r_{11} k-1}\right]\left[\frac{\sum \sigma_{b}{ }^{2}}{1-\sigma_{t}{ }^{2}}\right]
$$


Keterangan :

$r_{11}$ : reliabilitas instrumen

k : banyak butir pertanyaan

$\sum \sigma_{\mathrm{b}}^{2}$ : jumlah ragam butir

$\sigma_{t}^{2} \quad$ : ragam total hasil pengukuran

Analisis regresi digunakan untuk mengetahui hubungan yang ada di antara peubah bebas yang dinyatakan dalam persamaan matematika yaitu peubah bebas (Efektivitas Penerapan SMK3) dan peubah tidak bebas (Produktivitas). Rumus yang digunakan dalam analisis regresi ini adalah:

$$
\hat{Y}=a+b X
$$

Keterangan :

$\hat{Y} \quad$ : Peubah tidak bebas (produktivitas kerja karyawan)

a : Konstanta

b : Koefisien arah garis regresi

$\mathrm{X}$ : Peubah bebas (Efektivitas Penerapan SMK3)

n : Contoh

$$
\begin{aligned}
& a=\frac{\left(\sum y\right)\left(\sum x^{2}\right)-\left(\sum x\right)\left(\sum x y\right)}{n \sum x^{2}-\left(\sum x\right)^{2}} \\
& b=\frac{n \sum y x-\left(\sum x\right)\left(\sum y\right)}{n \sum x^{2}-\left(\sum x\right)^{2}}
\end{aligned}
$$

Laporan Analisa Kecelakaan Kerja diklasifikasikan menurut cidera ringan, cidera berat, fatality, dan property damage. Perhitungan yang dilakukan PT ITP untuk mengetahui tingkat statistik kecelakaan kerja, yaitu:

a. Tingkat Keseringan Kecelakaan (Injury Frequency Rate) digunakan untuk menghitung seluruh jumlah kejadian kecelakaan akibat kerja untuk setiap juta jam manusia (man hours), dengan rumus:

$$
\mathrm{IFR}=\frac{\sum \text { Kecelakaan }(\text { Lost time }>2 \text { hari }) \times 1.000 .00}{\text { Jumlah Jam Kerja }}
$$

b. Tingkat Keparahan Kecelakaan (Injury Severity Rate) digunakan untuk menghitung tingkat keparahan kecelakaan yang terjadi dan dihitung berdasarkan jumlah hari yang hilang untuk satu juta jam kerja manusia, dengan rumus :

$$
\text { ISR }=\frac{\sum \text { Waktu Yang hilang } \times 1.000 .00 . .}{\text { Jumlah jam kerja }}
$$


Pengukuran produktivitas digunakan sebagai sarana manajemen untuk menganalisa dan mendorong efisiensi produksi (Sinungan 2005). Tingkat produktivitas karyawan dapat dihitung dengan rumus:

$$
P=\frac{0}{1}
$$

Keterangan:

P : Tingkat produktivitas kerja karyawan

O : Tingkat output/hasil produktivitas (ton)

I : Tingkat input / jumlah jam kerja efektif karyawan

\section{Hasil Penelitian}

III.1. Gambaran Umum PT ITP, Tbk

PT ITP, Tbk merupakan perusahaan yang memproduksi semen dengan mengubah bahan mentah menjadi bahan jadi atau setengah jadi. PT ITP memiliki 12 plant yang terletak di Citeureup, Cirebon, dan Tarjun. PT ITP membangun 9 plant di Citeureup, 2 plant di Cirebon, dan 1 plant di Tarjun yang dibangun dalam kurun waktu 25 tahun. PT ITP mempunyai merek dagang "Cap Tiga Roda" sejak tahun 1975 dan memutuskan gopublic pada 16 Oktober 1989.

Pada tahun 1994 PT ITP menerapkan Total Quality Management (TQM) untuk meraih ISO 9001. Pada awal 1995, sertifikat ISO 9001 berhasil diraih oleh PT ITP dari Surveillance Generale societe (SGS) Surveyor. Penerapan TQM ini melibatkan seluruh SDM yang dimilikinya, maka diterapkan pula Sistem Manajemen Keselamatan dan Kesehatan Kerja (SMK3), agar SDM tetap memenuhi standar, tetap sehat, dan selamat dalam bekerja. Sertifikat untuk menilai bahwa SMK3 ini tetap berada pada standarnya adalah sertifikat OHSAS yang dikeluarkan oleh badan standar Internasional. Sertifikat ini diperoleh tahun 2000 dan diaudit minimal 2 tahun sekali.

Keselamatan dan kesehatan kerja dianggap sangat penting untuk diterapkan di PT ITP, dikarenakan proses produksinya mempunyai risiko sangat besar. Proses produksi semen dilakukan melalui beberapa tahapan, yaitu penambangan dan penyediaan bahan baku (Quarriying), pengeringan dan penggilingan bahan baku (Drying and Grinding), pembakaran dan pendinginan klinker (Kiln Burning and Cooling), penggilingan akhir (Finish Grinding), dan pengantongan (Packing).

\section{III.2. Pelaksanaan SMK3}

PT ITP menerapkan SMK3 semenjak tahun 2000 dengan standar yang digunakan adalah Permenaker No. 05/MEN/1996 dan OHSAS 18001. PT ITP mengkombinasikan agar penerapannya dapat diakui secara nasional dan internasional.

Manfaat dari penerapan SMK3 bagi PT ITP adalah:

1. Melindungi karyawan

2. Memperlihatkan kepatuhan terhadap peraturan dan perundang-undangan

3. Mengurangi biaya untuk pengobatan, perawatan, penggantian kecelakaan dan kerusakan.

4. Membuat sistem manajemen yang efektif

5. Meningkatkan kepercayaan dan kepuasan pelanggan. 
Tujuannya menciptakan lingkungan kerja yang aman, nyaman, dan bebas dari kecelakaan kerja (zero accident).

SMK3 merupakan sistem yang bertujuan mengurangi angka kecelakaan kerja dengan menggunakan tingkat manajerial. SMK3 membutuhkan komitmen atau tanggungjawab yang harus dilakukan semua pihak. Tanggungjawab SMK3 PT ITP terbagi atas tanggungjawab manajemen dan personal.

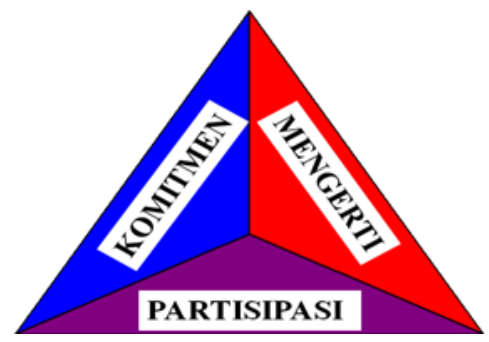

Gambar 2. Segitiga Tanggung Jawab SMK3

Segitiga tanggung jawab pada Gambar 2 merupakan simbol yang menunjukkan perusahaan dan setiap karyawan harus sadar sepenuhnya bahwa keselamatan dan kesehatan kerja adalah kewajiban dan tanggungjawab bersama. Manajemen selaku pemimpin perusahaan dan perwakilan karyawan membuat komitmen mengenai $\mathrm{K} 3$ dimengerti oleh para perwakilan karyawan serta dilakukan sosialisasi dengan komitmen agar dapat berpartisipasi untuk melaksanakan hal yang telah disepakati.

Penetapan peran dan tanggung jawab SMK3 dapat dilihat dari pembagian aktivitas kerja pada unit-unit K3 yang diterapkan di PT ITP terdiri atas:

1. Safety Department: pengendalian K3 tingkat perusahaan

2. Health Department: pemantauan dan pengukuran

3. Security Department: pusat pengendalian keadaan darurat

4. Plant/Division: pengendalian K3 di Plant/Division

5. QSMR: Audit dan tinjauan manajemen.

Model SMK3 yang diterapkan PT ITP diadopsi dengan menyesuaikan standar OHSAS 18001 dan Permenaker No. 05/MEN/1996. Model ini diterapkan berawal dari kebijakan lingkungan yag ditetapkan oleh PT ITP berupa Keselamatan dan Kesehatan Kerja, Keamanan, Lingkungan dan Masyarakat (K4LM). Manajemen PT ITP sudah menyadari bahwa pelaksanaan K3 tidak hanya untuk kebaikan karyawan, tetapi juga bermanfaat untuk perusahaan secara keseluruhan.

Pada tahap perencanaan SMK3 (Gambar 3), hal yang perlu dilakukan adalah pengidentifikasian bahaya potensial dan eveluasi risiko, pengidentifikasian undangundang dan persyaratan lainnya, membuat tujuan dan sasaran K3, serta menerapkan program manajemen K3. Pada tahap penerapan dan operasi, SMK3 ditinjau agar dapat dipastikan bahwa persyaratan SMK3 dibuat, diterapkan, dan dipelihara sesuai standar secara benar dan berjalan sesuai persyaratan di semua lokasi dan lingkungan operasi. Agar semuanya dapat berjalan benar dan sesuai, maka karyawan diberikan pelatihan mengenai K3 sesuai dengan kebutuhannya. Pemberian K3 ini dibedakan menjadi beberapa tingkatan yang disesuaikan dengan tanggungjawab, kemampuan, skill, dan risiko kerja karyawan. 


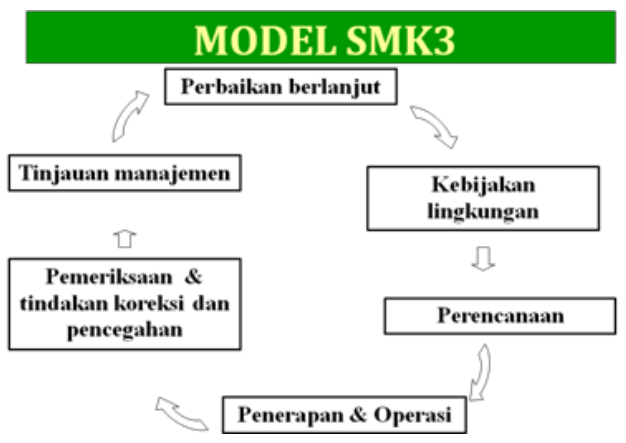

Gambar 3. Model Penerapan SMK3 (www.indocement.co.id)

Selain memberikan pelatihan, pengelolaan komunikasi penting dalam penerapan SMK3. Dengan konsultasi dan komunikasi, segala ketidaktahuan, kesalahpahaman dan permasalahan di dalam suatu organisasi dapat segera diatasi. PT ITP telah mengelola komunikasi tersebut dengan membentuk Panitia Pembina Keselamatan dan Kesehatan Kerja (P2K3), Sub P2K3, Safety Meeting dan Safety Talks. Keseluruhannya bertujuan mencegah terjadinya kecelakaan dan menginformasikannya kepada seluruh karyawan.

PT ITP diharapkan melakukan pengendalian dokumen SMK3 yang meliputi manual SMK3. MR bertanggungjawab dalam hal membuat Kebijakan K3, Manual dan Prosedur K3, serta Daftar Perundangan dan Standar. Sedangkan unit kerja (plant/divisi) bertanggungjawab untuk membuat tujuan dan sasaran, SOP manajemen risiko, SOP pengendalian operasi (perancangan dan pembelian), SOP penanganan material dan limbah, SOP keadaan darurat, SOP pemantauan dan pengukuran, SOP pengendalian ketidaksesuian dan tindakan koreksi. Dalam upaya pengendalian operasional, diberlakukan sistem izin kerja pada pekerjaan dan daerah-daerah yang teridentifikasi menurut hasil identifikasi potensi bahaya dan risiko. PT ITP juga menyediakan Alat Pelindung Diri (APD) untuk seluruh pekerja yang membutuhkan sesuai dengan tugas dan bahaya potensial yang telah diidentifikasi.

PT ITP telah menetapkan dan memelihara prosedur pemantauan dan pengukuran kinerja K3 sesuai dengan persyaratkan OHSAS 18001 mengenai pengukuran kinerja dan pemantauan, prosedur-prosedur pemantauan, dan pengukuran. PT ITP melaksanakan pemantauan dan pengukuran pada seluruh aspek yang menimbulkan risiko. Pemantauan yang dilakukan meliputi kegiatan:

1. Pemeriksaan kesehatan

2. Pemantauan lingkungan kerja (faktor fisika, kimia, biologi, ergonomi dan psikologi)

3. Pemantauan kinerja

Selain itu, PT ITP juga melakukan inspeksi K3 secara terencana dan terjadwal sebagai salah satu cara untuk mencegah kecelakaan kerja yang sesuai dengan prosedur inspeksi yang telah dibuat. Inspeksi bertujuan untuk mendapatkan gambaran kondisi lingkungan kerja dan hubungannya dengan K3 sehingga apabila terdapat potensi atau permasalahan K3 dapat segera diambil tindakan perbaikan.

Tahapan yang dapat menilai tingkat penerapan SMK3 adalah audit yang dilakukan oleh pihak internal dan eksternal perusahaan. Audit internal dilakukan oleh QSMR PT ITP sebanyak 2 kali dalam setahun dan audit ekternal dilakukan oleh badan sertifikasi Sucofindo sebanyak 3 tahun sekali. Dari tahun 2000, PT ITP mendapat penghargaan 
dari Sucofindo berupa golden flag. Penghargaan ini diberikan atas pencapaian penerapan SMK3 yang telah memenuhi kriteria lebih dari $84 \%$. Tujuan audit SMK3 adalah memberikan masukan-masukan untuk perbaikan kinerja SMK3 di perusahaan agar berjalan secara efektif.

Tinjauan manajemen dilakukan untuk menjamin kesesuaian, kecukupan dan keefektifan SMK3. Sedangkan untuk output yang diharapkan dari diadakannya suatu tinjauan manajemen adalah mencakup suatu keputusan/tindakan yang berkaitan dengan:

1. Perbaikan pada keefektifan kinerja SMK3 dan lingkungan.

2. Perbaikan pada proses produksi dan produk yang berkaitan dengan aspek lingkungan penting dan K3.

3. Sumber daya yang diperlukan untuk penerapan SMK3.

4. Rekomendasi program K3 selanjutnya.

Hal-hal tersebut dilakukan agar terjadi perbaikan yang berkelanjutan, sehingga pelaksanaan SMK3 di PT ITP dapat lebih baik lagi.

\section{III.3. Efektivitas Pelaksanaan SMK3}

Pelaksanaan SMK3 PT ITP telah dilaksanakan sesuai dengan prosedur yang telah ditetapkan. Hal ini dapat terlihat dari penghargaan golden flag yang diberikan badan sertifikasi Sucofindo. Selain dari golden flag, efektifitas penerapan SMK3 dapat dilihat dari jumlah kecelakaan yang terjadi di suatu divisi (plant). Pada penelitian ini, efektivitas penerapan SMK3 dilihat dari penurunan angka kecelakaan kerja yang terjadi di P-11. P-11 mempunyai tingkat kecelakaan yang tinggi pada awal beroperasinya. Hal ini dikarenakan, P-11 merupakan plant terbesar dengan jumlah karyawan terbanyak. Tabel 2 menunjukkan angak kecelakaan yang terjadi di P-11 dari tahun 2000-2007.

Tabel 2. Tingkat Keseringan dan Tingkat Keparahan Kecelakaan Kerja

\begin{tabular}{cccccc}
\hline Tahun & Jumlah Karyawan & IFR & Standar IFR & ISR & Standar ISR \\
\hline 2000 & 272 & 5 & 2,5 & 76 & 55,5 \\
2001 & 259 & 6 & 2,0 & 106 & 37,5 \\
2002 & 261 & 8 & 1,5 & 97 & 24,7 \\
2003 & 253 & 5 & 1,0 & 17 & 16,5 \\
2004 & 227 & 2 & 0,5 & 6 & 11,0 \\
2005 & 225 & 1 & 0,5 & 7 & 11,0 \\
2006 & 213 & 0 & 0,5 & 0 & 11,0 \\
2007 & 200 & 0 & 0,5 & 0 & 11,0 \\
\hline
\end{tabular}

Sumber: www.indocement.co.id 2007

Pada Tabel 2 dapat dilihat bahwa jumlah tenaga kerja terus menurun dari tahun ke tahun, dikarenakan banyak karyawan yang pensiun. Karyawan pensiun tersebut tidak digantikan dengan merekrut karyawan baru karena PT ITP sedang melakukan pengurangan karyawan tanpa melalui proses PHK.

Secara garis besar, tingkat keseringan kecelakaan (IFR) dan tingkat keparahan kecelakaan (ISR) P-11 PT ITP berfluktuatif dari tahun 2000 hingga 2007. Hingga tahun 2005, IFR dan ISR yang terjadi di P-11 selalu berada di atas standar yang ditetapkan, sehingga penerapan SMK3 masih dianggap belum maksimal. Namun penurunan angka IFR dan ISR terus terjadi dari tahun 2003, dikarenakan PT ITP menghadapi audit 
eksternal untuk yang kedua kalinya sehingga perbaikan secara menyeluruh dan terorganisir dengan baik dilakukan oleh PT ITP. Hal yang dilakukan pada P-11, antara lain pelatihan tentang K3 yang dilakukan secara lebih baik, sosialisasi penggunaan APD yang lebih intensif dan safety talks yang lebih digiatkan.

Mulai tahun 2003, pelaksanaan safety talks dan rapat Sub P2K3 terus meningkat dan semakin sering dilakukan dengan peserta yang semakin banyak. IFR dan ISR menunjukkan penurunan berarti di P-11 hingga mulai tahun 2006 hampir tidak pernah terjadi kecelakaan di P-11 dalam 1.000 .000 jam kerja. Hal ini merupakan suatu prestasi bagi P-11 karena mencapai zero accident. Dapat disimpulkan bahwa penerapan SMK3 telah efektif mengurangi kecelakaan kerja yang terjadi di P-11 dilihat dari tingkat IFR dan ISR yang sebagian besar menurun dari tahun 2000-2007.

\section{III.4. Pengolahan dan Analisis Data}

Usia responden yang dominan pada penelitian ini adalah karyawan yang berada pada rentang usia 31-40 tahun. Pada rentang usia ini karyawan berada pada rentang produktif. Biasanya pada usia 31-40 tahun, karyawan telah memiliki pengalaman kerja. Tidak adanya karyawan yang berusia di bawah 20 tahun, karena mulai tahun 2006 PT ITP membuat kebijakan untuk merekrut karyawan dengan tingkat pendidikan minimal Strata 1 (S1), sehingga usianya lebih dari 20 tahun.

Penelitian ini dilaksanakan di Plant yang merupakan daerah dengan tingkat risiko kecelakaan tinggi, karena berupa pabrik tempat proses produksi dilakukan. Karyawan berjenis kelamin laki-laki sangat mendominasi dan jumlah wanita hanya berjumlah 2-5 orang. Pada penelitian ini $100 \%$ responden berjenis kelamin laki-laki, karena wanita ditempatkan pada bagian kantor dan administrasi. Karyawan laki-laki ditempatkan di plant karena laki-laki dinilai lebih waspada dan dapat bekerja lebih sigap dibandingkan wanita. Disamping itu, laki-laki cenderung dapat bepikir cepat tanpa melibatkan perasaan. Selain itu, di PT ITP jumlah karyawan wanita dengan pria adalah 1 berbanding 4 (data tahun 2007) dan lebih dari 90\% wanita ditempatkan di bagian kantor.

Pendidikan terakhir karyawan P-11 yang dominan adalah lulusan SMA dan sederajat. Lulusan ini mendominasi sebanyak 82,83\%, karena plant membutuhkan karyawan yang memiliki keahlian khusus untuk memenuhi kualifikasi yang dibutuhkan, seperti mesin-mesin, otomotif, dan listrik. Sebagian besar karyawannya merupakan lulusan STM atau SMK, 17,16\% merupakan karyawan lulusan S1. Lulusan S1 ini belum mendominasi karena pada tahun 2006 PT ITP baru membuat kebijakan mengenai pendidikan terakhir calon karyawan minimal D3.

Masa kerja karyawan PT ITP sebagian besar lebih dari 15 tahun karena PT ITP terakhir melakukan rekrutmen dalam jumlah besar pada tahun 1997. Setelah tahun itu, ketidakstabilan perekonomian negara berpengaruh juga pada keberlangsungan PT ITP, sehingga baru melakukan rekrutmen lagi pada tahun 2006. Pada P-11, $60 \%$ responden memiliki masa kerja lebih dari 15 tahun, 37 \% 11-15 tahun dan $3 \%$ kurang dari 3 tahun. Masa kerja di atas 15 tahun mendominasi karena untuk bekerja di plant dibutuhkan karyawan yang berpengalaman dalam bekerja.

Kuesioner disebarkan secara proporsional random sampling, karena P-11 memiliki beberapa departemen, yaitu Electical Department, Mechanical Department, dan 
Production Department. P-11 memiliki jumlah karyawan 200 orang dengan proporsi 110 orang pada Production Department, 51 orang pada Mechanic Department, dan 35 orang pada Electrical Department. Agar proporsi responden sesuai dengan yang tujuan maka jumlah responden dari Production Department mengisi dengan jumlah paling banyak 54,48\%, Mechanic 26,87\%, dan Electrical 18,66 \% dari 134 jumlah responden. Production Department mendominasi, karena departemen produksi merupakan departemen inti dari plant, karena proses produksi semen dikerjakan tanpa henti, maka untuk menunjang hal tersebut dibutuhkan karyawan dalam jumlah paling banyak agar tujuan yang ditetapkan dapat tercapai.

Kuesioner dibuat untuk mengetahui pendapat dan fakta yang dirasakan responden mengenai efektifitas penerapan SMK3 di P-11 PT ITP. Sebelum kuesioner disebar dilakukan suatu uji validitas. Uji validitas dilakukan setelah 30 kuesioner disebarkan. Uji Validitas dilakukan untuk mengetahui sampai sejauh mana data yang ditampung pada suatu kuesioner dapat mengukur apa yang ingin diukur. Suatu pernyataan pada kuesioner dinyatakan valid apabila $r_{\text {hitung }}$ lebih besar dari $r_{\text {tabel. }}$. Tingkat kesalahan yang ditetapkan sebesar $5 \%$, maka nilai $r_{\text {tabel }} 0,361$. Setelah uji validitas dilakukan, dari seluruh pertanyaan dapat disimpulkan bahwa seluruhnya valid dan dapat dijadikan sebagai alat ukur untuk mengukur persepsi karyawan mengenai efektifitas penerapan SMK3 di P-11 PT ITP.

Uji Reliabilitas dilakukan setelah uji validitas. Uji Reliabilitas digunakan untuk mengetahui sejauhmana alat ukur dapat diandalkan, apabila digunakan untuk mengukur gejala yang sama. Hasil pengukuran reliabilitas menyatakan bahwa kuesioner yang disebarkan dapat diandalkan untuk dijadikan alat ukur pada penelitian ini. Nilai ini jauh lebih besar dari nilai $\alpha$ teori, maka disimpulkan bahwa kuesioner yang disusun adalah dapat diandalkan.

\section{III.5. Analisis Persepsi Karyawan Terhadap Pelaksanaan SMK3 di P-11 PT ITP}

Analisis persepsi karyawan terhadap pelaksanaan SMK3 di P-11 dilakukan berdasarkan teori Miner yang dilihat dari lima aspek yaitu, pelatihan keselamatan kerja, publikasi keselamatan kerja, kontrol terhadap lingkungan kerja, inspeksi dan disiplin, serta peningkatan kesadaran K3. Masing-masing aspek diwakili dengan lima buah pertanyaan yang menggambarkan aspek-aspek tersebut. Tabel 3 menggambarkan skor rataan yang diperoleh dari persepsi karyawan terhadap lima aspek K3.

Tabel 3. Skor Rataan Aspek K3

\begin{tabular}{clc}
\hline No & \multicolumn{1}{c}{ Aspek K3 } & Skor Rataan \\
\hline 1. & Pelatihan Keselamatan Kerja & 2,84 \\
2. & Publikasi Keselamatan Kerja & 2,78 \\
3. & Kontrol Lingkungan Kerja & 2,98 \\
4. & Inspeksi dan Disiplin & 2,88 \\
5. & Peningkatan Kesadaran K3 & 3,03 \\
\hline & TOTAL & $\mathbf{2 . 9 0}$ \\
\hline
\end{tabular}

Tabel 3 menunjukkan bahwa persepsi karyawan terhadap pelaksanaan pelatihan keselamatan kerja telah dilaksanakan dengan baik. Karyawan berpendapat bahwa pelatihan SMK3 dilaksanakan sesuai dengan kebutuhan karyawan. Pelatihan yang 
diberikan kepada seluruh karyawan mulai dari pelatihan pengenalan hingga pelatihan pendalaman SMK3.

Pelatihan SMK3 yang diberikan kepada karyawan berdasarkan pada tingkat eselon dan jenis pekerjaannya. Apabila karyawan mendapatkan tugas untuk bekerja dengan keahlian khusus, maka pelatihan yang diterimanya berbeda dari karyawan yang lainnya. Materi pelatihan yang diberikan merupakan materi terbaru yang diperoleh pihak perusahaan dari badan-badan sertifikasi nasional maupun internasional. Hal ini diberikan kepada karyawan, agar dapat terus memperbaharui pengetahuannya mengenai SMK3 dan dapat terhindar dari kecelakaan kerja yang dapat merugikan dirinya maupun perusahaan.

Persepsi karyawan P-11 terhadap aspek publikasi keselamatan kerja adalah baik. Publikasi keselamatan kerja yang dilakukan berupa sosialisasi hal-hal yang berkaitan dengan SMK3, seperti sosialisasi program K3, penggunaan APD, alat pemadam kebakaran, working permit, safety talks dan rapat Sub P2K3. PT ITP telah memprogramkan sosialisasi pentingnya penggunaan APD, karena dapat menghindarkan karyawan dari bahaya yang muncul kapan saja selama karyawan bekerja dan berada di lingkungan perusahaan. P-11 terus disosialisasi kepada hal-hal yang berkaitan dengan SMK3 karyawan secara rutin. Media yang digunakan beragam, mulai dari papan pengumuman, rapat SubP2K3, Safety Talks, hingga media intranet yang digunakan di lingkungan PT ITP. Cara-cara tersebut dinilai efektif, karena hampir semua karyawan dapat memperoleh informasi mengenai $\mathrm{K} 3$.

Pada Tabel3 dapat dilihat bahwa kontrol terhadap lingkungan kerja telah dilaksanakan dengan baik oleh PT ITP. Kontrol lingkungan kerja yang dimaksud adalah pengendalian dan pemeriksanaan terhadap karyawan dan perlengkapan kerjanya. Pemeriksaan kesehatan yang dilaksanakan dan wajib diikuti adalah general check up, non general check up, pemeriksaan berkala, pelaporan penyakit menular dan vaksinasi. Hal lain yang diperhatikan oleh PT ITP untuk mengontrol lingkungan kerjanya adalah kondisi ruang kerja, perlengkapan kerja karyawan seperti APD, seragam kerja, safety shoes, serta perlengkapan keselamatan yang wajib ada pada setiap ruangan seperti peralatan keadaan darurat dan kotak P3K. Setiap kali dilaksanakan audit internal, perlengkapan dan peralatan keselamatan tersebut selalu diperiksa. Apabila terdapat ketidaksesuaian, maka dilakukan tindakan lanjutan seperti mengganti atau memperbaikinya.

Berdasarkan persepsi karyawan mengenai aspek inspeksi dan disiplin pada Tabel 3, karyawan menyatakan bahwa aspek ini telah dilaksanakan dengan baik. Karyawan berpendapat bahwa kewajiban menggunakan APD paling efektif dalam mengurangi kecelakaan kerja, karena kecelakaan yang paling sering terjadi disebabkan kelalaian karyawan dalam bekerja. Penggunaan APD sangat membantu karyawan untuk menghindarkan diri dari kecelakaan kerja. APD diberikan kepada karyawan sesuai dengan jenis dan tingkat risiko pekerjaannya. Dalam hal ini PT ITP pun telah membuat peraturan-peraturan yang mengatur kehidupan kerja karyawan yang dirangkum dalam Perjanjian Kerja Bersama (PKB). Peraturan tersebut memuat juga mengenai sanksi, apabila karyawan melanggar peraturan yang telah disepakati. Cara lain yang efektif dalam mengurangi kecelakaan kerja adalah pemasangan tanda peringatan dan tanda bahaya di instalasi berpotensi bahaya terutama di P-11. 
Berdasarkan Tabel 3, karyawan merasa bahwa kesadaran terhadap K3 telah meningkat. Hal ini ditunjukkan dengan kesadaran karyawan akan pentingnya K3 dalam bekerja. Karyawan pun telah memiliki motivasi yang baik untuk melaksanakan K3. Hal ini dikarenakan Safety Dept. memiliki cara yang baik dalam mengingatkan karyawan untuk bekerja dengan mengutamakan keselamatan. Perusahaan telah membuat SOP yang baik tentang persyaratan dan prosedur kerja yang sesuai standar K3. Karyawan merasa telah memprioritaskan bekerja sesuai dengan standar $\mathrm{K} 3$ dan hal ini dilakukan untuk menghindarkan karyawan dari kecelakaan dan timbulnya penyakit akibat kerja, sehingga karyawan memiliki motivasi baik untuk melaksanakan program K3 ini.

Dapat disimpulkan bahwa, pelaksanaan SMK3 di PT ITP, khususnya dari persepsi karyawan P-11 telah berjalan dengan baik dan efektif dalam mengurangi angka kecelakaan kerja, meskipun masih ada hal yang perlu diperbaiki, seperti pembentukan satgas K3 dan sosialisasi working permit, agar pelaksanaan K3 dapat lebih baik.

\section{III.6. Analisis Tingkat Produktivitas Kerja Karyawan}

Pada Tabel 4 dapat dilihat bahwa tingkat produktivitas kerja karyawan cenderung meningkat dari tahun 2000-2007. Tingkat produktivitas kerja karyawan selalu berada di atas standar yang ditetapkan. Tingkat produktivitas kerja karyawan di P-11 menunjukkan peningkatan positif dari tahun ke tahun dan mendekati keadaan ideal dari tingkat produktivitas kerja yang baik. Hal ini ditunjukkan dengan output yang terus meningkat dan berbanding terbalik dengan jumlah karyawan dan jam kerjanya. Bila output terus meningkat dan input yang digunakan seefisien mungkin maka produktivitas yang dihasilkan semakin tinggi dan optimal.

Tabel 4. Tingkat Produktivitas Kerja Karyawan P-11 PT ITP tahun 2000-2007

\begin{tabular}{ccccc}
\hline Tahun & $\begin{array}{c}\text { Volume } \\
\text { Produksi } \\
\text { (Ton) }\end{array}$ & $\begin{array}{c}\text { Jam Kerja } \\
\text { Per Tahun }\end{array}$ & $\begin{array}{c}\text { Tingkat Produktivitas } \\
\text { Kerja Karyawan } \\
\text { (Ton) }\end{array}$ & $\begin{array}{c}\text { Standar Produktivitas } \\
\text { Kerja Karyawan } \\
\text { (Ton) }\end{array}$ \\
\hline 2000 & 2.005 .769 & 618.316 & 3,24 & 0,55 \\
2001 & 2.001 .479 & 640.789 & 3,12 & 0,60 \\
2002 & 2.149 .740 & $636.560,5$ & 3,38 & 0,60 \\
2003 & 2.218 .405 & 595.867 & 3,72 & 0,66 \\
2004 & 2.347 .171 & $535.844,5$ & 4,38 & 0,66 \\
2005 & 2.038 .579 & 469.522 & 4,34 & 0,70 \\
2006 & 2.228 .428 & 442.361 & 5,04 & 0,70 \\
2007 & 2.291 .001 & 385.790 & 5,94 & 0,70 \\
\hline
\end{tabular}

Sumber: www.indocement.co.id 2007

\section{III.7. Analisis Pengaruh Efektivitas SMK3 Terhadap Produktivitas Kerja Karyawan}

Pada analisis Regresi Linear Sederhana peubah independen yang digunakan adalah SMK3 yang dilihat dari tingkat keseringan kecelakaan kerja (IFR) dan tingkat keparahan kecelakaan kerja (ISR). Untuk peubah dependen yang digunakan adalah tingkat produktivitas kerja karyawan P-11 PT ITP dari tahun 2000-2007. Pada perhitungan besarnya pengaruh peubah independen terhadap peubah dependen ditetapkan peubah IFR sebagai $X_{1}$ dan ISR sebagai $X_{2}$ sedangkan produktivitas kerja karyawan sebagai $Y$.

Berdasarkan hasil analisis diperoleh persamaan regresi linear sebagai berikut: 
Peubah IFR $\left(X_{1}\right)$ memiliki t hitung $-4,531$ dengan tingkat nyata 0,004 . Hal ini berarti signifikansi $t<0,05$, sehingga dapat disimpulkan peubah tingkat keseringan kecelakaan berpengaruh nyata terhadap produktivitas kerja karyawan. Nilai koefisien beta $-0,286$ dan bentuk hubungan negatif berarti semakin kecil tingkat keseringan kecelakaan, maka semakin tinggi pengaruhnya terhadap produktivitas kerja karyawan. Dari hasil perhitungan, diperoleh nilai $\mathrm{R} 0,880$, berarti korelasi antara peubah dependen $(Y)$ dengan peubah independen $(X)$ adalah positif yang berarti terdapat hubungan antara peubah dependen dan peubah independen. Dari nilai Adjusted $R$ Square (koefisien yang telah disesuaikan) menunjukkan nilai sebesar 0,736 yang berarti bahwa peubah $X_{1}$ mampu menjelaskan model sebesar $73,6 \%$ sedangkan sisanya $26,4 \%$ dijelaskan oleh peubah lain di luar dari peubah yang diteliti.

Peubah ISR (X2) tidak masuk ke dalam persamaan regresi tersebut karena nilai signifikan X2 lebih besar dari 0,05 (5\%) yaitu 0,718, maka tingkat keparahan kecelakaan (ISR) tidak nyata mempengaruhi produktivitas kerja karyawan. Hal ini cenderung dipengaruhi oleh tingkat kecelakaan yang tergolong parah adalah minimal 2 hari. Meninjau dari karakteristik karyawan, lost time 2 hari merupakan hal yang wajar sehingga pekerjaan dapat digantikan oleh orang lain dan tidak mengganggu produktivitas kerja plant.

Dapat disimpulkan bahwa IFR secara nyata mempengaruhi produktivitas kerja karyawan. Jika IFR berada pada tingkat 0, maka produktivitas kerja karyawan 5,109 ton. Untuk itu PT ITP mengambil tindakan dengan mengantisipasi tingkat IFR, agar tetap berada pada tingkat 0 dengan terus meningkatkan mutu dan kuantitas pelaksanaan SMK3, terutama untuk menekan IFR. IFR cenderung dipengaruhi oleh tindakan karyawan yang lalai dalam bekerja (unsafe action), sehingga mengakibatkan kecelakaan terjadi, dalam hal ini PT ITP, khususnya P-11 agar lebih baik dalam menerapkan standar SMK3 yang selama ini sudah dijalankan, terutama dari kebijakan lingkungan yang dibuat, perencanaan, penerapan dan operasi, pemeriksaan, tindakan koreksi dan pencegahan, tinjauan manajemen, serta perbaikan yang berkelanjutan. Hal tersebut merupakan model SMK3 yang diterapkan di PT ITP.

\section{Kesimpulan}

PT ITP telah menerapkan SMK3 berdasarkan standar OHSAS 18001 dan Permenaker No. 05/MEN/1996. Penerapan tersebut dilakukan baik, sehingga mendapat penghargaan Golden Flag dari PT. Sucofindo sejak tahun 2000. Tingkat keseringan kecelakaan IFR dan Tingkat keparahan kecelakaan ISR dari P-11 cenderung menurun hingga tahun 2007 sejak pertama kali beroperasi tahun 2000 dan telah mencapai zero accident pada tahun 2006 dan 2007. Pelaksanaan SMK3 di P-11 telah berjalan dengan baik dan efektif mengurangi angka kecelakaan kerja, terutama dengan penggunaan APD. Selain itu, Karyawan P-11 sangat merasakan manfaat dari pemeriksaan kesehatan rutin. Tingkat produktivitas kerja karyawan P11 PT ITP selalu berada di atas standar yang ditetapkan dan tingkat produktivitas tersebut cenderung meningkat dari tahun 2000-2007. Hal ini menunjukkan bahwa 
P-11 telah beroperasi secara efektif dan efisien. Tingkat keseringan kecelakaan IFR secara nyata mempengaruhi tingkat produktivitas kerja karyawan $-0,286$ dan berpengaruh negatif, sehingga dapat dikatakan semakin kecil tingkat frekuensi kecelakaan, maka semakin tinggi tingkat produktivitas kerja karyawan PT ITP.

\section{Daftar Pustaka}

Mangkuprawira S. dan Vitayala Hubeis. 2007. Manajemen Mutu Sumber Daya Manusia, Ghalia Indonesia, Bogor.

Sinungan, M. 2005. Produktivitas Apa Dan Bagaimana, Bumi Aksara, Jakarta.

Umar, H. 2003. Riset Sumber Daya Manusia Dalam Organisasi, PT. Gramedia Pustaka Utama, Jakarta.

www.indocement.co.id. 2007. 